\title{
Investigation of Relationship between Communication in Academic Environment and Quality of Work Life among Academic Staff
}

\section{Özden Tepeköylü Öztürk ${ }^{1}$ \\ Mümine Soytürk² (iD Hüseyin Gökçe ${ }^{3}$}

${ }^{. s}$ Pamukkale University Faculty of Sport Sciences, Denizli, Turkey Email:otepehovlu@hotmail.com Tel:+905325416466

'Email: hsyngki@gmail.com Tel: +905055023258

${ }^{2}$ Celal Bayar University Faculty of Sport Sciences, Manisai, Turkey

EEmail:sovturkmumine@gmail.com Tel: +905067813363

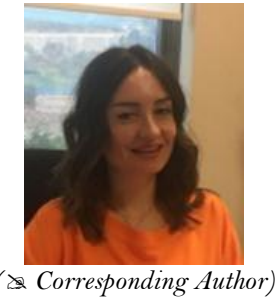

( Corresponding Author)

\section{Abstract}

In this study, it is aimed to identify the relationship between the communication in academic environment and quality of work life of the academic staff who work in the field of sports sciences. Moreover, the administrational functions of each variable are studied considering the academic titles. The research is a quantitative-correlational study. The sample of the study is formed by 51 women and 114 men out of 165 academic staff who work in the field of sports sciences at various universities in Turkey. In the study, as data collection tools, "Quality of Work Life Scale" and "Communication Analysis Inventory in Academic Environment" are used. Data are assessed using Pearson correlation analysis, multiple linear regression analysis and t-test. It is noted with the findings that communication in academic environment (CAE) and quality of work life (QWL) have moderate and negative relations and sub-dimensions of both variables have weak, low and moderate negative relations. Also, it is indicated that CAE is a significant predictor of QWL. It's stated that while academic staff who have administrative position perceives the CAE and its subdimensions positively (except for the insufficient share of scientific knowledge and sub-dimensions of faculty atmosphere), QWL gets higher scores only in sub-dimensions about relations with colleagues,work satisfaction and taking responsibility in the office. According to academic title (except for sub-dimension of individuality), there has been found no significant difference in QWL and its sub-dimensions.

Keywords: Communication in academic environment, Quality of life, Interpersonal communication, Organizational communication.

Citation | Özden Tepeköylü Öztürk; Mümine Soytürk; Hüseyin Gökçe (2019). Investigation of Relationship between Communication in Academic Environment and Quality of Work Life among Academic Staff. Asian Journal of Education and Training, $5(1): 280-286$.

$5(1): 280-286$
History:

History:

Revised: 11 February 2019

Accepted: 6 March 2019

Published: 20 March 2019

Licensed: This work is licensed under a Creative Commons

Attribution 3.0 License $(\mathrm{ccc}) \mathbf{E}$

Publisher: Asian Online Journal Publishing Group
Contribution/Acknowledgement: All authors contributed to the conception and design of the study.

Funding: This study received no specific financial support.

Competing Interests: The authors declare that they have no conflict of interests.

Trerests. Transparency: The authors confirm that the manuscript is an honest,
accurate, and transparent account of the study was reported; that no vital features of the study have been omitted; and that any discrepancies from the study as planned have been explained.

Ethical: This study follows all ethical practices during writing.

\section{Contents}

1. Introduction

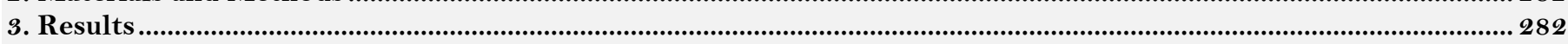

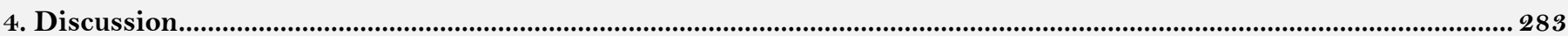

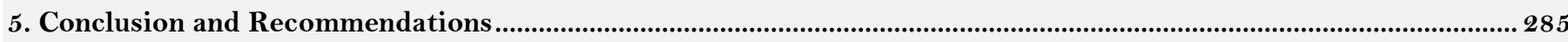

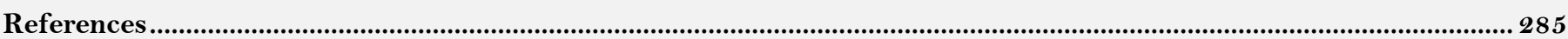




\section{Introduction}

Universities, known as the last degree of education by the society and providing knowledge and skills as to market needs, are complex organizations (Afşar-Taşdemir, 2015). Both complex structure of them and the necessity of the accurate and quick flow of information convey the organizational communication to a significant point. No matter how the structure in organization or decentralisation is obviously clear, proper running of these mechanisms and success in coordination is possible by means of intra-organizational communication (Ö̉çer and Koçer, 2015). Organizational communication is a constant interaction with individuals and external environment to provide running of the organization and perform the organizational aims (Ada et al., 2008). A successful and sustainable structure is not possible for organizations experiencing problems in communication paths that convey the transmission of messages from one unit to another (Yanı, 2015). Effective communication might affect many factors such as the current structure of organization, its culture, run of authority (Vural, 2003).

When analyzed in terms of characteristics of structural communication, it can be mentioned about formal communication which hints the authority and control on employee and informal communication which is spontaneous and less structural according to formal communication. According to message direction, it is faced with vertical, horizontal and diagonal communication features (Arslan and Arslan, 2007). While formal communication carries out basic management processes especially in coordination, informal communication serves purposes such as making things easier in organizations, constituting consensus, sharpening differences and being target-oriented. In addition to these aspects, it provides a vast number of benefits to the institutions due to being fast and fluent (Güllüoğlu, 2012). When organizations are generally examined, it is seen that the direction of message is vertical and horizontal. Horizontal communication, which is a coordination provider, accompanies to this structure which can be a sample of chain of command. Especially during crisis, diagonal communication, which is more complicated, is also used in comparison with these two structures (Genç, 2004).

When considered from universities point of view, it is difficult to build and pursue an effective communication environment because of administration at universities, structuring of organization and characteristics of personnel. Accordingly, determining process quality of communication in academic environment (CAE), following periodically and explanation the relationship with different variables are regarded significant. Quality of work life (QWL), being a variable that is related to human resources in organizations, can also be regarded as a concept which could be examined together with the process of organizational communication. QWL, which is occurred with the contemporary management approaches, states personnel's degree of satisfying needs, work satisfaction and motivation (Cicek, 2005). These factors ranging in a positive way is possible with keeping obvious the communication channels at all levels and using them effectively and efficiently. When viewed in a detailed perspective, Quality of work life is defined as a concept which includes weak and strong aspects such as satisfaction with officers, working conditions, productivity, communication in organization, method of management (Martel and Dupuis, 2006). Ozaslan (2010) states that quality of work life is not merely related to work satisfaction, it is also a concept that is used to explain the relations with life out of work, individual and internal happiness. Therefore, quality of work life is affected by both experiences related to work and various factor which affects these experiences (Easton and Laar, 2013) in addition to the positive factors about work, it affects the factors such as stress, alienation and burnout positively (Newstrom and Davis, 1997).

When quality of work life literature is researched, as one of the first occupations that comes to mind, health staff is regarded a subject which is studied more on when examined in terms of working conditions, risks it contains and performances of professionals. Johnsrud (2002) divides the studies into three main groups which he researches about quality of work life in his scientific journal. The ones in the first group are studies defining and explaining studies, in the second group factors that affect quality of work life and in the last group explaining the behavioural results. Studies are found examining the concept of quality of work life in terms of education sector. In a study that is carried out by Putt and Springer (1980) who lecture in the field of public administration to define the personnel's work satisfaction, detached from many factors that affect the work satisfaction, it is stated that decision-making process is the most significant factor on satisfaction and at this point, it is referred to professional life satisfaction which is a parameter that is related to quality of work life. Soytürk and Tepeköylü-Öztürk (2017) analyze the quality of work life of physical education teachers according to various personal and occupational features. They sign that teachers who are happy with their jobs have higher quality of work life. In the study that is carried out by Erdem (2008) The predictive degree of the quality of work life, their loyalty to schools and organizational dependence of quality of work life of the teachers who work both for public or private schools is examined. As a result of the study, it is indicated that the teachers who work for public schools have lower quality of work life than the ones who work for private schools in many dimensions. Ozaslan (2010) analyses the professional life qualities of the research assistants. He comes to a conclusion that research assistants generally do not take part in the decisions made at universities. According to the result of the study conducted by AfşarTaşdemir (2015) to determine the quality of work life of researchers, it is proved that participants' quality of work life differs in terms of academic title, salary, their way of employment, job security and total number of working years at universities. When literature is researched in terms of CAE, Gizir (1999) has conducted a study on the most common communication problems of academic staff they face in their own department, other departments in the same faculty and other departments of the university and in order to analyse solution recommendations, and it is found that individuality, insufficient share of scientific knowledge, lack of motivation, alignment, managerial problems, lack of common purpose, criticism, introspective features of department and communication of department atmosphere are factors that affect in a negative way. It is tried to determine by Argon and Kösterelioğlu (2009) whether researchers' perception of communication changes as to some variables or not. As a result, it is found that the academic staff's academic communication level varies considering gender, title, age, working period of time at the faculty and department variables.

Based on these statements in this study, in addition to complicated university structure, it is aimed to determine predictive relationship between academic staff's CAE and QWL who are a part of universities with multidisciplinary structure of sports and who work in the field of Sports sciences. Also, each variable's differences are analysed according to administrative mission situation and academic title variables. 


\section{Materials and Methods}

\subsection{Research Design and Study Group}

This research is a correlational and comparative study. Quantitative research techniques have been used. The study group of the research consists of 51 women and 114 men in total 165 academic staff (age $=43.06 \pm 10.04$ years), who work in the field of sports sciences at many universities in Turkey. Academic staff is included in the research considering voluntariness. 165 academic staff takes part in the research despite being reached to 1565 academic staff.

\subsection{Data Collection Tools}

In the study as data collection tools, "Quality of work life scale" (QWLS) developed by McDonald (2001) and adapted into Turkish by Akin-Kösterelioğlu (2011) "Communication Analysis Inventory in Academic Environment" (CAIAE) developed by Gizir and Gizir (2005) and "Personal Information Form" that is developed by the researchers have been used.

Quality of Work Life Scale (QWLS): The scale of quality of work life is a 5-point Likert type scale consisting of 40 items. It consists of seven dimensions (administrative support, non-work-related stress, income, relationships with colleagues, communication, degree of job satisfaction, use of skills and autonomy, responsibility and duty at work). The high score in the scale that opposite terms are involved indicate that the quality of work life is in good level. In the end of the analysis into structural validity of Akin-Kösterelioğlu (2011). It is determined that sub-item total correlations change from 0.32 to 0.58. The Cronbach's Alpha internal consistency coefficient of all scale is 0.94 while ) who adapted the scale into Turkish, the QWL scale could account for $46.30 \%$ of the total variance and each dimension's self-value is seen over $1 \%$ changes from 0.77 to . 0.90 . Within the scope of this study, the internal consistency coefficient of the total scale is determined as 0.87 .

Communication Analysis Inventory in Academic Environment (CAIAE): It is a 5-point Likert type scale used to determine academic personnel's perceptions of communication processes in academic environment. It consists of 36 items. It has 10 sub-dimensions including negative factors for communication processes in academic environment (lack of communication, individuality, insufficient share of scientific knowledge, lack of motivation, alignment, managerial problems, lack of common purpose, criticism, introspective features and atmosphere of department). The high score of items-also including reciprocal ones has shown that the communication in academic environment is also negative. In the construct validity analysis, it is seen that the factor loadings of the items in the inventory range from 0.44 to 0.90.According to the results of reliability studies, the alpha coefficient in the Cronbach's alpha internal consistency evaluation changes from 0.67 to 0.88 (Gizir and Gizir, 2005). Within the scope of this study, the internal consistency coefficient of the total scale is determined as 0.95 .

Personal Information Form (PIF): The information on the personal information of the research group and the independent variables of the research is determined by the Personal Information Form created by researchers. In this form, there are questions about the age, gender, titles of participants and whether they are in the administrative position or not.

\subsection{Data Collection}

The data has been collected via e-mail. Firstly, a list of universities containing the faculty and high school of sports science, or related to sports science departments is formed. The websites of these universities are visited, the addresses of the lecturers in sports sciences are recorded one by one, and another list is formed. The online scales are electronically sent to 1565 faculty members whose e-mail addresses can be reached 2 times in 2 weeks apart. We get feedback from 169 people, but 165 of them filled in accordance with measurement tools are evaluated.

\subsection{Statistical Analysis Data}

Data are evaluated by using frequency, arithmetic mean, standard deviation; Pearson correlation analysis, multiple linear regression analysis (backward model) and t-test statistical testing techniques. Pearson correlation analysis has been used to determine the relationship between the sub-dimensions and total scores of Communication in Academic Environment (CAE) and Quality of Work Life (QWL); and multiple linear regression analysis (backward model) has been used to decide if CAE predicts QWL or not. Differences in dependent variables according to the administrative task status and titles of faculty members are examined with t-test. Whether the data meet the prerequisites of parametric tests are decided by examining the skewness and kurtosis (normal distribution of data) values and Levene (equality of variances) tests. The mahalonobis distance of the data is calculated and multivariate normal distribution is also evaluated. The skewness and kurtosis values of data change from $-916 \pm .376$ to $-.568 \pm .189$.

In the correlation and regression analyzes, whether the relationship between the variables is linear or not has been decided by examining the dispersion diagram. In order to determine the reliability of the scales used in the study, Cronbach's alpha internal consistency coefficients have been calculated. Type 1 error is accepted as $5 \%$.

\section{Results}

Table-1. Descriptive statistics of communication in academic environment of academic staff and their quality of work life related to total score

\begin{tabular}{l|c|c|c|c|c}
\hline Factor & $\mathbf{n}$ & Min. & Max. & $\bar{X}$ & Std. Error \\
\hline $\begin{array}{l}\text { Communication in academic } \\
\text { environment }\end{array}$ & 165 & 1.08 & 4.81 & 2.83 & .74 \\
\hline Quality of work life & 165 & 2.25 & 4.43 & 3.27 & .45 \\
\hline
\end{tabular}


When the Table 1 is analyzed, it is seen that academicians'-who work in the field of sports sciencescommunication in academic environment is at a good level above the average (the scale is evaluated in reverse) and the quality of work life is at the middle level.

Table-2. Pearson correlation analysis to determine the relationship between communication in academic environment and quality

\begin{tabular}{|c|c|c|c|c|c|c|c|c|}
\hline$n=165$ & QWL1 $^{a}$ & QWL2 $^{b}$ & QWL3 $^{b}$ & QWLA ${ }^{d}$ & QWL5 $^{\mathrm{e}}$ & QWL6 $^{f}$ & QWL7" & TotalQWL \\
\hline $\mathrm{CAE}{ }^{1}$ & $-.476 * *$ & $-.382 * *$ & -.051 & $-.677 * *$ & $-.355 * *$ & $-.265 * *$ & $-.502^{*} *$ & $-.620 * *$ \\
\hline $\mathrm{CAE}^{2}{ }^{2}$ & $-.439 * *$ & $-.297 * *$ & -.008 & $-.510 * *$ & $-.323 * *$ & $-.161 * *$ & $-.543 * *$ & $-.506 * *$ \\
\hline CAE3 $^{3}$ & $-.421 * *$ & $-.272 * *$ & -.021 & $-.512 * *$ & $-.381 * *$ & -.151 & -.399 ** & $-.489 * *$ \\
\hline $\mathrm{CAE}^{4}{ }^{4}$ & $-.360 * *$ & $-.216 * *$ & -.073 & $-.195^{*}$ & $-.253 * *$ & $-.188^{*}$ & $-.393 * *$ & $-.401 * *$ \\
\hline CAE $5^{5}$ & -.119 & $-.264 * *$ & .031 & $-.280 * *$ & -.061 & -.031 & $-.305^{* *}$ & $-.243^{* *}$ \\
\hline CAE $6^{6}$ & $-.604 * *$ & $-.294 * *$ & -.024 & $-.430 * *$ & $-.376 * *$ & -.108 & $-.535 * *$ & $-.572 * *$ \\
\hline $\mathrm{CAE}^{7}$ & $-.527 * *$ & $-.306 * *$ & .047 & $-.445 * *$ & $-.441 * *$ & -.145 & $-.510^{*} *$ & $-.538 * *$ \\
\hline $\mathrm{CAE}^{8}{ }^{8}$ & $-.476^{* *}$ & $-.331 * *$ & .058 & $.452^{* *}$ & $-.296 * *$ & -.130 & $-.406 * *$ & $-.486 * *$ \\
\hline CAE9 $^{9}$ & $-.315^{* *}$ & $-.276 * *$ & .005 & $-.312 * *$ & $-.252 * *$ & -.150 & $-.284 * *$ & $-.373 * *$ \\
\hline CAE9 $^{9}$ & $-.564 * *$ & $-.362 * *$ & -.023 & $-.640 * *$ & $-.358 * *$ & $-.287 * *$ & $-.338 * *$ & $-.606 * *$ \\
\hline Total CAE & $-.597 * *$ & $-.401 * *$ & -.013 & $-.611 * *$ & $-.419 * *$ & $-.222 * *$ & $-.557 * *$ & $-.661 * *$ \\
\hline
\end{tabular}

** $\mathrm{p}<0.01$ (2-tailed); *p<0.05 (2-tailed).

-1Poor communication, 2Individualism, 3Inadequate sharing of scientific knowledge, 4Lack of motivation, 5Alignment, 6Administrative problems, 7Lack of common goals, 8Criticism, 9Inward-looking character of the department, 10Departmental atmosphere

-aAdministrative support, bNon-work-related stress, cIncome, dRelationships with colleagues, eCommunication, fJob satisfaction and encourage, gResponsibility and duty at work

When Table 2 is analyzed, it is seen that in general there is a strong, medium and weak significant relationship in a negative way between the total score and sub-dimensions of CAE and the total score and sub-dimensions of QWL while there is no relationship between the income sub-dimension of QWL and CAE. Accordingly, it can be said that as the level of the negative components in the communication processes in the academic environment increases, QWL is decreasing. When the relationship levels are analyzed, while the strongest relationship is found between the poor communication sub-dimension of CAE and relationships with colleagues sub-dimension of QWL; the lowest relationship is found between lack of motivation sub-dimension of CAE and non-work-related stressed sub-dimension of QWL.

Table-3. Results of the multiple linear regression analysis for predicting the quality of work life related to the sub-dimensions of communication in academic environment.

\begin{tabular}{|c|c|c|c|c|c|}
\hline Variable & B & Standard Error в & $\beta$ & $\mathrm{t}$ & $\mathrm{p}$ \\
\hline Constant & 176.900 & 3.899 & \multirow[b]{2}{*}{-.307} & 45.369 & .000 \\
\hline Poor communication & -1.206 & .301 & & -4.000 & .000 \\
\hline Lack of motivation & -.995 & .371 & -.163 & -2.684 & .008 \\
\hline Administrative problems & -.521 & .250 & -.160 & -2.086 & .039 \\
\hline Departmental atmosphere & -1.038 & .286 & -.271 & -3.623 & .000 \\
\hline
\end{tabular}

$\mathrm{R}=.715 ; \mathrm{R} 2=.512 ;$ Corrected $\mathrm{R} 2=.499$

$\mathrm{F}_{(4,164)}=41.893 ; \mathrm{p}=.000$.

When the regression analysis is examined Table 3, it is seen that poor communication, administrative problems and departmental atmosphere sub-dimensions of CAE is a significant predictor of QWL $\left(\mathrm{R}=.715 ; \mathrm{R} 2=.512 ; \mathrm{F}_{(4}\right.$, $\left.{ }_{164)}=41.893 ; \mathrm{p}=.000\right)$. The stated variables explain $51 \%$ of the total variance in quality of work life. According to the standardized regression coefficient $(\beta)$ and $t$ values, the relative order of predictive variables on the quality of work life is respectively lack of motivation, poor communication, departmental atmosphere, administrative problems.

When Table 4 is analyzed, it is seen that there are significant differences between total score of CAE scale and its sub-dimensions -except for alignment according to administrative mission status- and relationships with colleagues, level of job satisfaction and encouragement, usage of skills and autonomy, and taking in responsibility and duty at work sub-dimensions. According to this, academic staff who has an administrative role perceives communication in academic environment more positively; similarly, they perceive quality of work life more positively from specified sub-dimensions of the QWL scale.

When Table 5 is analyzed, it is seen that there is a significant difference in individuality-the sub-dimension of CAE- according to the title variable. According to this, it can be said that non-lecturer academic staff feels more individual in communication in academic environment. According to the title, there is no significant difference in CAE total score and its sub-dimensions; and QWL total score and its sub-dimensions.

\section{Discussion}

According to the findings of the study, the communication of the academicians in academic environments almost good-level near the mid-level while their quality of work life is in the mid-level. According to Winter et al. (2000), universities are suffering from chaos in their mission and responsibilities. The universities that are trying to centralization by keeping their organisational respect through cost efficiency should, meanwhile, offer service in different sectors and so they are obliged to get away from centralization by enlarging their income spectrum. This situation may also cause different missions, responsibilities, extra work-load, stress and chaos in the communication process for each personnel within the university, especially the academicians. For this reason, the mid-level quality of work life and academic environment communication is considered an expected finding. When the relations between the two variables are studied, it is observed that the communication in the academic environment is closely related to quality of work life and it explains the $51 \%$ of the variation in QWL. In other words, as the negative factors affecting the communication in the academic environment rises, the quality of work life declines. Declares that communication invariably affects attitudes, the feeling of satisfaction and work satisfaction in the workplace. In the research conducted by Muchinsky (1977) organizational communication is 
considered highly related to the interpersonal environment, responsibility, administration and the organizational climate pointing to the emotional state. Similarly, in the studies of Erogluer (2011) and Muchinsky (1977) organizational communication is referred as highly related to the work-satisfaction regarding administrators, workmates, the qualification of the work, wage and additional income.

\begin{tabular}{|c|c|c|c|c|c|c|c|}
\hline Variable & Administrative Mission & $\mathbf{N}$ & $\overline{\mathrm{X}}$ & sd & df & $\mathbf{t}$ & $\mathbf{p}$ \\
\hline \multirow[t]{2}{*}{ Poor communication } & No & 117 & 13.05 & 4.54 & 163 & 3.308 & $.001^{*}$ \\
\hline & Yes & 48 & 10.52 & 4.31 & & & \\
\hline \multirow[t]{2}{*}{ Individualism } & No & 117 & 12.70 & 3.52 & 163 & 3.920 & $.000^{*}$ \\
\hline & Yes & 48 & 10.22 & 4.06 & & & \\
\hline \multirow{2}{*}{$\begin{array}{llll}\begin{array}{l}\text { Inadequate } \\
\text { knowledge }\end{array} & & & \\
\end{array}$} & No & 117 & 6.26 & 2.04 & 163 & 2.289 & $.023 *$ \\
\hline & Yes & 48 & 5.45 & 2.07 & & & \\
\hline \multirow[t]{2}{*}{ Lack of Motivation } & No & 117 & 9.06 & 3.02 & 163 & 2.245 & .026 \\
\hline & Yes & 48 & 7.93 & 2.71 & & & \\
\hline \multirow[t]{2}{*}{ Alignment } & No & 117 & 8.73 & 2.63 & 163 & 1.906 & .058 \\
\hline & Yes & 48 & 7.87 & 2.62 & & & \\
\hline \multirow[t]{2}{*}{ Administrative problems } & No & 117 & 18.35 & 5.30 & 163 & 3.390 & $.001^{*}$ \\
\hline & Yes & 48 & 15.22 & 5.59 & & & \\
\hline \multirow[t]{2}{*}{ Lack of common goals } & No & 117 & 9.31 & 3.11 & 163 & 3.342 & $.001^{*}$ \\
\hline & Yes & 48 & 7.52 & 3.18 & & & \\
\hline \multirow[t]{2}{*}{ Criticism } & No & 117 & 9.64 & 2.90 & 163 & 3.072 & $.002^{*}$ \\
\hline & Yes & 48 & 8.08 & 3.13 & & & \\
\hline \multirow{2}{*}{$\begin{array}{l}\text { Inward-looking character of the } \\
\text { department }\end{array}$} & No & 117 & 6.70 & 2.06 & 163 & 2.786 & $.006^{*}$ \\
\hline & Yes & 48 & 5.68 & 2.30 & & & \\
\hline \multirow[t]{2}{*}{ Departmental atmosphere } & No & 117 & 13.44 & 4.74 & 163 & 3.600 & $.000^{*}$ \\
\hline & Yes & 48 & 10.62 & 4.09 & & & \\
\hline \multirow[t]{2}{*}{ TotalCAE } & No & 117 & 107.31 & 25.20 & 163 & 4.134 & $.000^{*}$ \\
\hline & Yes & 48 & 89.16 & 26.58 & & & \\
\hline \multirow[t]{2}{*}{ Administrative support } & No & 117 & 24.07 & 6.98 & 163 & -.551 & .582 \\
\hline & Yes & 48 & 24.72 & 6.70 & & & \\
\hline \multirow[t]{2}{*}{ Non-work-related stress } & No & 117 & 32.59 & 6.22 & 163 & -.327 & .744 \\
\hline & Yes & 48 & 32.93 & 5.57 & & & \\
\hline \multirow[t]{2}{*}{ Income } & No & 117 & 14.12 & 5.00 & 163 & 1.303 & .194 \\
\hline & Yes & 48 & 13.02 & 4.82 & & & \\
\hline \multirow[t]{2}{*}{ Relationships with colleagues } & No & 117 & 14.00 & 2.94 & 163 & -2.923 & $.004^{*}$ \\
\hline & Yes & 48 & 15.45 & 2.76 & & & \\
\hline \multirow[t]{2}{*}{ Communication } & No & 117 & 9.34 & 1.83 & 163 & -1.849 & .066 \\
\hline & Yes & 48 & 9.97 & 2.38 & & & \\
\hline \multirow[t]{2}{*}{ Job satisfaction and encourage } & No & 117 & 21.94 & 3.57 & 163 & -.3651 & $.000^{*}$ \\
\hline & Yes & 48 & 24.00 & 2.38 & & & \\
\hline \multirow[t]{2}{*}{ Responsibility and duty at work } & No & 117 & 13.51 & 3.31 & 163 & -2.133 & 0.34 \\
\hline & Yes & 48 & 14.79 & 3.92 & & & \\
\hline \multirow[t]{2}{*}{ Total } & No & 117 & 129.94 & 18.27 & 163 & -1.758 & .088 \\
\hline & Yes & 48 & 134.91 & 17.30 & & & \\
\hline
\end{tabular}

The academic staff having administrational responsibilities regards their relations in the academic environment as more positive than the academicians who do not have. Concerning the quality of work life, they stated that their relations with their colleagues are better as well as higher work-satisfaction and they get more responsibilities. In the study Sarros et al. (1998) state that deans regard the maintenance of effective communication between departments as one of their most important responsibilities and moreover they have too many missions/responsibilities. The academic staffs who also have administrational positions are supposed to develop regular or irregular communication forms with the academicians in each level for the maintenance of the organizational aims. It is also assumed that the correct perception in missions and responsibilities, the maintenance of coordination among the staff and efficient inspection over the staff are closely related to the qualification of the administrator's communication. In addition, in the literary studies and in our study a good level communication is underlined to affect positively the parameters regarding the quality of work life. Therefore, the communication of the academic staff that have administrational positions may highly perceive the relations with collegues and work satisfaction. When it is considered in terms of those who do not have administrational positions, the researches indicate that the administrators in the faculties are lacking and their communicative relations are weak and they are not glad with the working conditions and the institutions (Boyer, Altbach, and Whitelaw, 1994; in cited from: Johnsrud (2002)).

When the findings of the research are interpreted according to the titles, it is indicated that both academic staff and other lecturers perceive the quality of work life and communication in academic environment similarly. However, instructors who are not academic members perceive more individuality in communication in academic environment. Gizir and Simsek (2005) the individuality results from the feelings of being dominant and having more knowledge and this case causes insufficient knowledge sharing within the organization. In their study, Winter et al. (2000) detected that the other academic staff than the academicians cannot be involved enough in the decision process and they are mostly informed very late of the decisions taken within the institution. 
Table-5. T-test results for comparison of CAE and QWL scores according to the title of academic staff.

\begin{tabular}{|c|c|c|c|c|c|c|c|}
\hline Variable & Title & $\mathbf{N}$ & $\overline{\bar{X}}$ & Sd & $\overline{d f}$ & $\bar{t}$ & $\mathbf{P}$ \\
\hline \multirow[t]{2}{*}{ Poor communication } & ${ }^{1}$ Academic Staff & 95 & 11.77 & 4.57 & 148.676 & -1.770 & .079 \\
\hline & ${ }^{2}$ Other & 70 & 13.05 & 4.58 & & & \\
\hline \multirow[t]{2}{*}{ Individualism } & Academic Staff & 95 & 11.37 & 4.03 & 163 & -2.401 & .017 \\
\hline & Other & 70 & 12.81 & 3.44 & & & \\
\hline \multirow[t]{2}{*}{ Inadequate sharing of scientific knowledge } & Academic Staff & 95 & 5.93 & 2.12 & 163 & -.671 & .503 \\
\hline & Other & 70 & 6.15 & 2.02 & & & \\
\hline \multirow[t]{2}{*}{ Lack of motivation } & Academic Staff & 95 & 8.69 & 2.90 & 143.381 & -.222 & .825 \\
\hline & Other & 70 & 8.80 & 3.09 & & & \\
\hline \multirow[t]{2}{*}{ Alignment } & Academic Staff. & 95 & 8.17 & 2.70 & 163 & -1.735 & .085 \\
\hline & Other & 70 & 8.90 & 2.54 & & & \\
\hline \multirow[t]{2}{*}{ Administrative problems } & Academic Staff & 95 & 16.85 & 5.85 & 163 & -1.613 & .109 \\
\hline & Other & 70 & 18.25 & 5.05 & & & \\
\hline \multirow[t]{2}{*}{ Lack of common goals } & Academic Staff & 95 & 8.58 & 3.29 & 163 & -.947 & ,345 \\
\hline & Other & 70 & 9.07 & 3.14 & & & \\
\hline \multirow[t]{2}{*}{ Criticism } & Academic Staff & 95 & 9.03 & 3.10 & 163 & -.796 & .427 \\
\hline & Other & 70 & 9.41 & 2.98 & & & \\
\hline \multirow{2}{*}{$\begin{array}{l}\text { Inward-looking character of the } \\
\text { department }\end{array}$} & Academic Staff & 95 & 6.15 & 2.19 & 163 & -1.753 & .081 \\
\hline & Other & 70 & 6.75 & 2.12 & & & \\
\hline \multirow[t]{2}{*}{ Departmental atmosphere } & Academic Staff & 95 & 12.34 & 4.93 & 163 & -.875 & .383 \\
\hline & Other & 70 & 13.00 & 4.44 & & & \\
\hline \multirow[t]{2}{*}{ TotalCAE } & Academic Staff & 95 & 98.94 & 27.57 & 163 & -1.733 & .085 \\
\hline & Other & 70 & 106.22 & 25.40 & & & \\
\hline \multirow[t]{2}{*}{ Administrative support } & Academic Staff & 95 & 23.54 & 6.74 & 145.585 & -1.560 & .121 \\
\hline & Other & 70 & 25.24 & 7.01 & & & \\
\hline \multirow[t]{2}{*}{ Non-work-related stress } & Academic Staff & 95 & 32.73 & 6.06 & 163 & .099 & .921 \\
\hline & Other & 70 & 32.64 & 6.01 & & & \\
\hline \multirow[t]{2}{*}{ Income } & Academic Staff & 95 & 13.71 & 5.05 & 163 & -.271 & .787 \\
\hline & Other & 70 & 13.92 & 4.88 & & & \\
\hline \multirow[t]{2}{*}{ Relationships with colleagues } & Academic Staff & 95 & 14.62 & 3.03 & 163 & .964 & .336 \\
\hline & Other & 70 & 14.17 & 2.85 & & & \\
\hline \multirow[t]{2}{*}{ Communication } & Academic Staff & 95 & 9.55 & 2.33 & 163 & .226 & .822 \\
\hline & Other & 70 & 9.48 & 1.52 & & & \\
\hline \multirow[t]{2}{*}{ Job satisfaction, encouragement } & Academic Staff & 95 & 22.68 & 3.55 & 163 & .610 & .543 \\
\hline & Other & 70 & 22.35 & 3.19 & & & \\
\hline \multirow[t]{2}{*}{ Responsibility and duty at work } & Academic Staff & 95 & 14.13 & 3.79 & 163 & 1.067 & .288 \\
\hline & Other & 70 & 13.54 & 3.14 & & & \\
\hline \multirow[t]{2}{*}{ Total } & Academic Staff & 95 & 131.00 & 18.44 & 163 & -.130 & .897 \\
\hline & Other & 70 & 131.37 & 17.78 & & & \\
\hline
\end{tabular}

\section{Conclusion and Recommendations}

In this study, it is concluded that the communication of academicians in the sports science field is in the midlevel. Besides, this communication process invariably affects their quality of work life to a large extent. Concerning a general overview, the academic personnel whose ranks are lower do not see the organizational communication process as efficient enough and they define the process as individual. That's why, it is concluded that the academicians, especially the ones who are also in administration position, should care more about sharing of the knowledge and they should be more involved in the decision process. Judging from the assumption that each academicians who are also in the administration position are not equal to each other in terms of their administrational knowledge and skill, the prospective administrators should be given in-service training to prevent the problems related to them in addition to put some criteria such as gaining experience for a certain time.

\section{References}

Ada, N., I. Alver and F. Atli, 2008. The effects of organizational communication on the organization commitment: A research aplied on empleyees of manufacturing sector on organized industrial zone of Manisa. Ege University Ege Academic Review, 8(2): 487-518.

Afşar-Taşdemir, S., 2015. Reading quality of work life through academicians Hacettepe University. Education Science Society Journal, 13(50): 134-173.

Akin-Kösterelioğlu, M., 2011. The relationship between work and life alienation of primary school teachers. PhD Thesis, Aban İzzet Baysal University Institute of Social Sciences, Bolu, Turkey.

Argon, T. and M.A. Kösterelioğlu, 2009. Academic communication levels of academicians in terms of variables. Electronic Social Sciences Journal, 8(30): 43-61.

Arslan, E. and B. Arslan, 2007. Organizational communication (Uğur Demiray, Ed.), General Communication. Ankara: I Pegeen. 99: 141182.

Cicek, D., 2005. Motivation and quality of work life (OWL) in organizations: A research about by determining the motivation level of managers in public organization and developing their QWL. PhD. Thesis, Cukurova University Graduate School of Social Sciences, Adana, Turkey.

Easton, S. and V.D. Laar, 2013. Evaluation of outcomes and quality of working life in the coaching setting. The Coaching Psychologist, 9(2): $71-77$.

Erdem, M., 2008. The relationship between the quality of work life and organizational commitment in public and private high schools according to teachers. PhD Thesis, Ankara University, Higher Education Council National Thesis Center, Ankara, Turkey.

Erogluer, K., 2011. The relationship between organizational communication and the aspects of job satisfaction: A theoretical study. Ege Academic Review, 11(1): 121-136.

Genç, N., 2004. Management and organization. 4th Edn., Ankara, Turkey: Seçkin Publishing.

Gizir, S., 1999. Communication in an academic context: The Middle East technical university. Master Thesis, Middle East Technical University, Ankara, Turkey. 
Gizir, S. and C.A. Gizir, 2005. Inventory of communication analysis in academic context Mersin university. Journal of Faculty of Education, $1(1): 112-125$

Gizir, S. and H. Simsek, 2005. Communication in an academic context. Higher Education, 50(2): 197-221.Available at: https://doi.org/10.20535/2410-8286.131690

Güllüoğlu, O., 2012. Organizational communication \& communication satisfaction and organizational commitment. 2nd Edn., Konya, Turkey: Education Publication.

Johnsrud, L.K., 2002. Measuring the quality of faculty and administrative worklife: Implications for college and university campuses. Research in Higher Education, 43(3): 379-395.

Martel, J.-P. and G. Dupuis, 2006. Quality of work life: Theoretical and methodological problems, and presentation of a new model and measuring instrument. Social Indicators Research, 77(2): 333-368.Available at: https://doi.org/10.1007/s 1 1205-004-5368-4.

McDonald, S.A., 2001. User's guide quality of work life. UK: NFERNELSON Publishing Company Ltd. Darville House, UK.

Muchinsky, P.M., 1977. Organizational communication: Relationships to organizational climate and job satisfaction. Academy of Management Journal, 20(4): 592-607.Available at: https://doi.org/10.5465/255359.

Newstrom, J.W. and K. Davis, 1997. Organizational behavior: Human behavior at work. Boston: Mc Graw Hill.

Ölçer, N. and S. Koçer, 2015. Organizational communication: A study on the academic staff of Kocaeli university. Global Media Journal TR Edition, 6(11): 339-383.

Ozaslan, G., 2010. Evaluation of working life quality of research assistants. Selçuk university institute of social sciences. PhD. Thesis, Konya, Turkey.

Putt, A. and J. Springer, 1980. Quality of work life among public administration professors. International Journal of Public Administration, 2(2): 225-246.Available at: https://doi.org/10.1080/01900698008524381.

Sarros, J.C., W.H. Gmelch and G.A. Tanewski, 1998. The academic dean: A position in need of a compass and clock. Higher Education Research \& Development, 17(1): 65-88.Available at: https://doi.org/10.1080/0729436980170104.

Soytürk, M. and Ö. Tepeköylü-Öztürk, 2017. The examination of work life quality of physical education teachers. Celal Bayar University Journal of Physical Education and Sport Sciences, 12(2): 12-23.

Vural, A.B., 2003. Corporate culture. 1st Edn., Istanbul, Turkey: Communication Publications.

Winter, R., T. Taylor and J. Sarros, 2000. Trouble at mill: Quality of academic worklife issues within a comprehensive Australian university. Studies in Higher Education, 25(3): 279-294.Available at: https://doi.org/10.1080/713696158.

Yanık, M., 2015. The effect of sports type and some other variables on the communication skill levels of physical education and sports college students. Journal of Human Sciences, 12(2): 1366-1376. 